\title{
Left ventricular function, morphology, and myocardial tissue characterization in Sickle Cell Disease: a multi-modality imaging study
}

\author{
Ahmad Homaa ${ }^{1 *}$, Ankit A Desai ${ }^{2}$, Roberto M Lang ${ }^{1}$, Thejasvi Thiruvoipati ${ }^{1}$, Kristen Turner ${ }^{3}$, Lynn Weinert ${ }^{1}$, \\ E Bruce Jamison ${ }^{1}$, Nicole Artz ${ }^{3}$, Sharon Trevino², Sharon Feehan ${ }^{1}$, Roberto Machado², Joe GN Garcia², \\ Amit R Patel ${ }^{1}$
}

From 2011 SCMR/Euro CMR Joint Scientific Sessions Nice, France. 3-6 February 2011

\section{Objectives}

Our aim was to characterize the cardiac morphology, function and myocardium in patients with sickle cell disease (SCD) using CMR and transthoracic echocardiography (TTE).

\section{Background}

Cardiovascular complications are a major cause of death in SCD yet the mechanism remains unclear.

\section{Methods}

Thirty-one stable, African-American outpatients with SCD (mean age $32 \pm 8$ yrs) prospectively underwent CMR (Philips 1.5 Tesla) and TTE (Philips iE33). Retrospectivelygated cines of left ventricular (LV) 2-, 3-, and 4-chamber, and short axis cine stack were obtained using SSFP (temporal resolution $25-40 \mathrm{~ms}$ ). Late gadolinium enhancement (LGE) images of the same views were obtained 10-20 minutes after infusion of Gd-DTPA $(0.15 \mathrm{mmol} / \mathrm{kg})$ using phase sensitive inversion recovery (TR $4.5 \mathrm{~ms}$, TE $2.2 \mathrm{~ms}$, TI $250-300 \mathrm{~ms}$, flip angle $30^{\circ}$, PSIR flip angle $5^{\circ}$ ).

Single short-axis, mid-ventricular myocardial T2* slice and coronal, hepatic $\mathrm{T} 2 *$ slice were acquired with a single breath-hold, at six echo-times (2.3 to $14 \mathrm{msec}$ ) using a gradient echo sequence. Tissue T2* signal intensity was measured in LV septum and liver at two separate echo times and $\mathrm{T} 2 *=-\Delta \mathrm{TE} / \mathrm{ln}\left(\mathrm{SI}_{\mathrm{TE} 2} / \mathrm{SI}_{\mathrm{TE} 1}\right)$ where $\triangle \mathrm{TE}$ represents time difference between the two echo times and $\mathrm{I}_{\mathrm{TE} 1}$ and $\mathrm{I}_{\mathrm{TE} 2}$ represent signal intensity at

'University of Chicago Medical Center, Chicago, IL, USA

Full list of author information is available at the end of the article echo time one and two. Myocardial and hepatic T2* were abnormal if $<20 \mathrm{~ms}$ and $<18 \mathrm{~ms}$, respectively.

CMR LV volumes, ejection fraction (EF), and mass were calculated using method of disks and indexed for body surface area. The presence or absence of LGE was determined. Diastolic dysfunction (DD) was identified based on echocardiographic measurements including tissue Doppler (age adjusted E/A ratio) and left atrial volumes.

\section{Results}

SCD patients had preserved LVEF with enlarged biventricular and LA volumes. DD was present in 15 (48\%). LGE

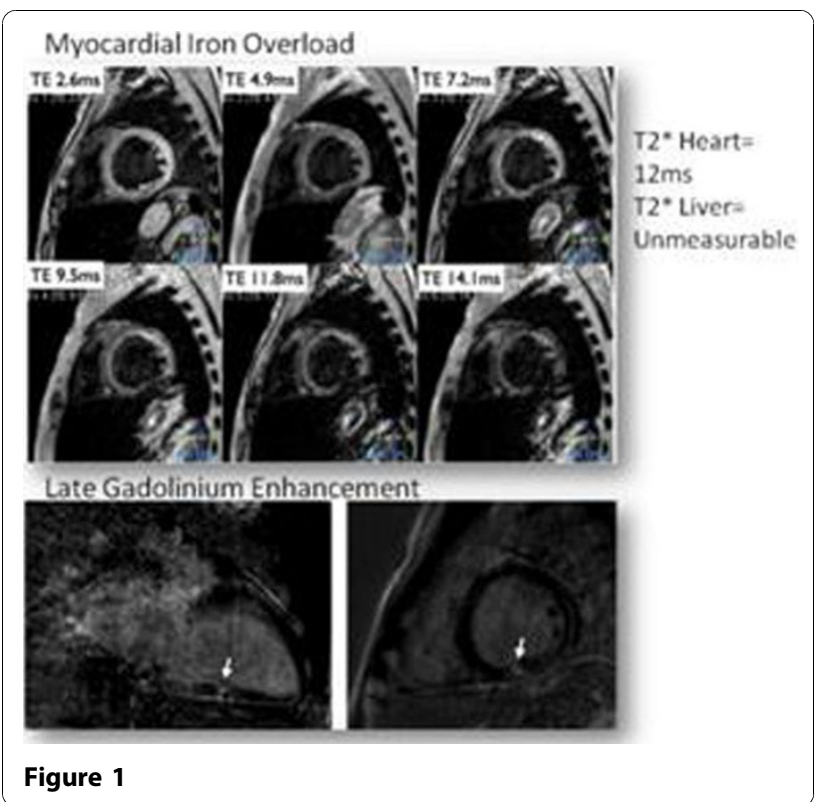

(C) 2011 Homaa et al; licensee BioMed Central Ltd. This is an open access article distributed under the terms of the Creative Commons 
Table 1

\begin{tabular}{|c|c|c|c|c|}
\hline & All Study Patients $(n=31)$ & No LGE $(n=24)$ & Positive LGE $(n=7)$ & $p$-value \\
\hline LV EF (\%) & $58.3 \pm 7$ & $58.4 \pm 5$ & $58.9 \pm 12$ & 0.92 \\
\hline LVEDV (mL) & $224.8 \pm 61$ & $217 \pm 57$ & $251.1 \pm 62$ & 0.25 \\
\hline LVEDV Index $\left(\mathrm{mL} / \mathrm{m}^{2}\right)$ & $124.2 \pm 29$ & $118.9 \pm 27$ & $142.6 \pm 25$ & 0.07 \\
\hline LV mass $(\mathrm{g})$ & $141.1 \pm 40$ & 135.638 & $159.9 \pm 36$ & 0.18 \\
\hline LV mass Index $\left(\mathrm{g} / \mathrm{m}^{2}\right)$ & $78.1 \pm 20$ & $74.3 \pm 18$ & $91.3 \pm 17$ & 0.06 \\
\hline RVEDV $(\mathrm{mL})$ & $227.2 \pm 59$ & $222.3 \pm 60$ & $244.3 \pm 50$ & 0.38 \\
\hline RVEDV Index $\left(\mathrm{mL} / \mathrm{m}^{2}\right)$ & $125.5 \pm 27$ & $121.4 \pm 27$ & $139.4 \pm 22$ & 0.12 \\
\hline LA volume $(\mathrm{mL})$ & $117.1 \pm 34$ & $112.2 \pm 33$ & $134 \pm 26$ & 0.11 \\
\hline T2* Myocardial Iron (msec) & $42.2 \pm 13$ & $45 \pm 11$ & $34 \pm 16$ & 0.18 \\
\hline T2* Hepatic Iton (msec) & $17.9 \pm 14$ & $21.7 \pm 13$ & $4.9 \pm 3$ & $<0.01$ \\
\hline
\end{tabular}

was noted in 7 (23\%), myocardial iron overload in 2 (7\%) and hepatic iron overload in 16 (52\%). (Figure 1) Those with LGE had significantly lower hepatic T2* $(\mathrm{p}<0.01)$ and a trend towards having a larger LVEDV index, LV mass index, RVEDV index, and LA volumes. (Table 1) Woman with LGE (versus women without LGE) had significantly larger LVEDV index $133.4 \pm 9$ versus $108.4 \pm 25(\mathrm{p}=0.01)$, RVEDV $230.3 \pm 13$ versus $193.9 \pm 41(p=0.02)$, and LA volume $146.7 \pm 15$ versus $94.2 \pm 20(\mathrm{p}=0.01)$.

\section{Conclusion}

SCD patients had significant chamber dilation, DD, and LGE. Those with LGE had significantly more hepatic iron overload suggesting a greater disease severity requiring more blood transfusions. Women with LGE demonstrated more severe adverse remodeling. Myocardial iron overload was rare.

\section{Author details}

${ }^{1}$ University of Chicago Medical Center, Chicago, IL, USA. ${ }^{2}$ Univeristy of Illinois at Chicago, Chicago, IL, USA. ${ }^{3}$ Loyola Medical Center, Chicago, IL, USA.

Published: 2 February 2011

doi:10.1186/1532-429X-13-S1-P334

Cite this article as: Homaa et al:: Left ventricular function, morphology, and myocardial tissue characterization in Sickle Cell Disease: a multimodality imaging study. Journal of Cardiovascular Magnetic Resonance 2011 13(Suppl 1):P334.
Submit your next manuscript to BioMed Central and take full advantage of:

- Convenient online submission

- Thorough peer review

- No space constraints or color figure charges

- Immediate publication on acceptance

- Inclusion in PubMed, CAS, Scopus and Google Scholar

- Research which is freely available for redistribution

Submit your manuscript at www.biomedcentral.com/submit 